\title{
LOGISTICS FOR HUMANITARIAN AID
}

\author{
Marcin Paweska \\ FCILT International University of Logistics and Transport, Wroclaw, Poland
}

OMESTE

JEL Category: F52, H84

\begin{abstract}
The modern world, in addition to the developing modern civilization and democracy, is characterized by the constant threat and emergence of extraordinary events in various forms. These events have a negative impact on human safety and security across the world, but especially in developing countries, with a weak economy and democracy. This entails the need for humanitarian aid for people affected by extraordinary incidents, especially in countries where governments for various reasons are unable to provide all citizens with necessary help. In this article, the author explains the concepts of humanitarianism and humanitarian aid and presents its main goals and the basic principles of its conduct. This includes legislative framework as well as key principles of delivering humanitarian aid. It also characterizes the main humanitarian aid providers across the world including states, intergovernmental (transnational) organizations (IGOs), and non-governmental organizations (NGOs). Next, the article shows humanitarian aid providers specific to Poland.
\end{abstract}

Keywords: security, threat, aid, humanitarianism

\section{INTRODUCTION}

The changes of recent years in a geopolitical, military and natural environment encourage continuous identification and assessment of security problems. Safety as one of the basic social needs expands its meaning. This is not only a defense against military aggression. The contemporary dimension of security is also the readiness to protect against dangerous phenomena of both military and non-military nature, and thus to protect people, their goods and the environment in various crisis situations.

The contemporary development of the human population is increasingly accompanied by anthropogenic, natural, technical and technological disasters and their effects in the

\author{
Address of the author: \\ Marcin Paweska \\ 䒠/mpaweska@msl.com.pl
}

form of huge damage and losses. This implies the need to re-evaluate the basic values of the development of the modern world.

Today, fundamental values are widely recognized: achieving a higher level of quality of life, protection of life and health of citizens, maintaining the quality of the natural environment, securing the spiritual values of societies, creating the right material conditions for life and ensuring their protection, ensuring fair social relations with an emphasis on international relations and, what the authors believe most importantly - raising the level of broadly understood comprehensive security. (Simak, Seidl, \& Zamiar, 2009)

The safety of the state and its citizens in each country is not only the object of practical steps but also of theoretic elaboration of these issues and scientific research of the essence of security itself, its methods and tools by which it is being achieved (Simak \& Ristvej, 2009). Maintaining a high level of security in the $21^{\text {st }}$ century is one of the most 
important tasks that societies, national governments, and international organizations face. The $21^{\text {st }}$ century means, on the one hand, the positive aspects of modernity, among others: the greatest development of civilization; scientific and technical progress; development of democracy; strengthening international cooperation through international security systems and the subjugation of nature and the universe more and more.

On the other hand, these positive aspects often manifest themselves in the present day with a negative impact on security, among others these are: famine, poverty, and suffering; technologies that make life easier, but often pose mass threats; rising unemployment, organized crime and terrorism; wars, armed conflicts, religious and national conflicts; ecological disasters, natural disasters, industrial failures.

The above negative phenomena can and often are the cause of conflicts, among which the most general can be distinguished: conflicts between man and nature; conflicts between man and technology; conflicts between man and society; conflicts among societies (Simak L. , 2004). These and other conflicts can be a source of extraordinary events, with consequences that the governments of individual countries, due to the extent and severity of events, cannot cope with the forces and means they possess. In the event of a threat to human life and health, it is necessary to provide humanitarian aid.

Therefore, the purpose of this publication is to characterize and present the readers with the essence, goals, and rules of providing humanitarian aid in Polish and international terms. The basic research question was: Which institutions and to what extent provide humanitarian aid? In the investigations, among others, the analysis of literature and source materials were used, as well as a comparison.

\section{THE ESSENCE, GOALS, AND RULES OF PROVIDING HUMANITARIAN AID}

According to the Dictionary of the Polish language, humanitarianism comes from the Latin humanitas - humanity and sounds similar in many languages: English: humane, German: humanitär, French: humanitaire, and mean the choice of respect for man and concern for his/her good; humaneness.

Similarly, it is also defined in other source materials, e.g.: in the Dictionary of Literary Terms it is respect for man, his/her dignity, the desire to save him/her suffering; in the Lexicon of PWN is an attitude characterized by respect for life and people, a desire to save them suffering (Leksykon PWN, 1999) Therefore, it should be recognized that humanitarianism, which accepts human dignity as the highest value, and respect for life and health, orders in a way to comply with this principle. This principle is implemented through humanitarian aid provided by governments and governmental organizations, international organizations and non-governmental organizations.

Humanitarian aid in international law is defined as to provide a needs-based emergency response aimed at preserving life, preventing and alleviating human suffering and maintaining human dignity wherever the need arises if governments and local actors are overwhelmed, unable or unwilling to act. (EUCOUNCIL, 2008).

Similarly, humanitarian aid is defined in publications and national regulations. In national institutions organizing and implementing humanitarian aid is understood as, first, saving and protecting life during disasters caused by natural or human conditions, as well as (Grzebyk \& Mikos-Skuza, 2016):

- providing necessary assistance and support to people exposed to long-term crises and assistance in the so-called "forgotten crises";

- carrying out short-term reconstruction works, especially in the field of infrastructure and equipment, in close cooperation with local institutions, considering long-term development goals, if possible;

- overcoming difficulties related to the consequences of migration of the population (refugees, displaced persons, and repatriates), caused by natural disasters or catastrophes caused by human activity;

- actions to prevent disasters and limit their consequences.

In the same documents, we read that the primary goal of humanitarian aid is to save and sustain life and to ensure respect for human dignity for people threatened or affected by the effects of natural 
disasters as well as those caused by human activities. This assistance also includes activities in the areas of prevention and mitigation of the effects of extraordinary events.

Funds for humanitarian aid come from the special reserve of the state budget administered by the Development Cooperation Department of the Ministry of Foreign Affairs. In situations of very severe crises, other state bodies may also decide to provide humanitarian aid from the funds at their disposal (Grzebyk \& Mikos-Skuza, 2016).

Poland conducts humanitarian activities in accordance with international standards, rules, and patterns of behavior. As a signatory to the 'European Consensus on Humanitarian Aid', it complies with the Code of Conduct for the International Red Cross and Red Crescent Movement and non-governmental organizations in crisis response programs. As a member of Good Humanitarian Donorship (GHD) ${ }^{1}$ and Sphère, it adheres to the Principles and Good Practice of Humanitarian Donorship ${ }^{2}$ and Humanitarian Charter and Minimum Standards in Humanitarian Response $^{3}$ and the recommendations of the World Health Organization (UN) (Grzebyk \& Mikos-Skuza, 2016).

The implementation of humanitarian aid should be carried out according to four basic rules (Grzebyk \& Mikos-Skuza, 2016):

- humanitarianism - any human being should be treated humanely under all conditions, which is manifested in saving human life and relieving suffering while respecting the individual;

- impartiality - the basis for humanitarian aid must be only the need, providing humanitarian aid must not be dependent on nationality, race, religion or political views;

- neutrality - the provision of humanitarian assistance is not connected with supporting one of the parties to the armed conflict or other dispute during which humanitarian aid is organized;

\footnotetext{
${ }^{1}$ GHD is an initiative established to effectively acquire, manage and distribute humanitarian aid in the world. An agreement on this matter was signed at a meeting in Stockholm on 16-17 June 2003 and there were agreed detailed guidelines from NGOs, the Red Cross and the
}

- independence - meaning autonomy of humanitarian and political, economic and military goals.

The key principle of the humanitarian aid provided by Poland is its compliance with the real needs of the aggrieved population - preceded by thorough analysis, and the funds allocated for it are to be allocated in a proportion corresponding to the scale of the crisis. The appeals and reports of humanitarian agencies of the UN and the International Committee of the Red Cross (ICRC) are of importance in the analysis of needs. This means that in the decision-making processes regarding the allocation of funds for humanitarian aid, Poland not only considers sudden, unforeseen and highly visible humanitarian crises but also so-called prolonged crises (protracted crises) and forgotten crises. Therefore, it is extremely important to observe the following rules (Grzebyk \& Mikos-Skuza, 2016).

- $\quad$ speed - it is important that help reaches the needy in the shortest possible time from the disaster, resulting in a humanitarian crisis. Efficient delivery of help means reducing the damage caused by a prolonged crisis (epidemics, hunger, weather conditions);

- adequacy - the aid should fully meet the needs of the population affected by the crisis. This means that it is necessary to obtain information from both the authorities of the recipient country and based on analyzes of Polish diplomatic missions, as well as from non-governmental organizations, in particular, international ones;

- possibly low administrative costs - the need to ensure that the costs of aiding (planning assistance, transport, and administrative support) are as low as possible in relation to the value of the support provided.

The demand for humanitarian aid in the world is systematically growing. The United Nations, the European Union, and independent humanitarian organizations support victims of natural disasters and conflicts, mainly in Africa and in Asia. The

UN on the provision of humanitarian aid. The initiative currently has 37 members, including Poland.

2 The principles and good practices in humanitarian aid.

3 The humanitarian card and minimum standards in the field of humanitarian aid. 
humanitarian policy also includes preventive measures to mitigate the effects of future disasters. The provision of humanitarian aid is a financial, logistical and organizational challenge.

Poland implements humanitarian aid respecting the principles presented, mainly but not only, through contributions to international institutions and co-financing of non-governmental humanitarian organizations. Humanitarian aid is also carried out by providing the needy with necessary products and material means (technical devices, medicines, clothing, food, hygiene, and cleanliness, etc.). In Poland, humanitarian organizations and agencies have a permanent, extensive aid distribution network. In implementing humanitarian needs, the most vulnerable groups among the victims are indicated, with emphasis on the needs of women, children, the elderly, the ill and the disabled.

The need to provide humanitarian aid is not only topical, but the demand for it is systematically growing. Since 1975, the number of natural disasters recorded in the world has increased from 75 to over 400 per year. In the years 2000-2006, almost two times more hydrometeorological disasters were recorded than in the years 1987 . 1998. The number of disasters caused by people has increased tenfold since 2000. The largest increase is observed in Africa and Asia (Zygierewicz, 2011).

\section{THE HUMANITARIAN PROVIDERS}

Currently, the main "donors" of humanitarian aid are states, intergovernmental (transnational) organizations (IGOs), the International Red Cross and Red Crescent Movement and nongovernmental organizations (INGOs). The terms "government organization", "intergovernmental organization", "state organization", "intergovernmental organization" are often used interchangeably (Kuzniak \& Marcinko, 2013).

In the case of intergovernmental organizations, the most important characteristic is that the members are states represented by representatives appointed by their governments. They receive power of attorney and instructions for action. For the organization of such an organization, a minimum of three countries is required, which will have a specific structure, principles, and mechanisms of action, as defined in the established statute (Latoszek \& Proczek, 2001).

In non-governmental organizations, however, members are natural or legal persons or natural and legal persons. They can be national associations or international associations of a public or private nature (Latoszek \& Proczek, 2001). Emergency management is a complex, dynamic process, and therefore, replacing human decision making by any form of automated process is far beyond the reach of current technology (Zagorecki, Ristvej, Comfort, \& Lovecek, 2012).

The obligation to provide humanitarian aid is in many international agreements, with the United Nations Charter deserving special attention, being an international document. Pursuant to Article 1 point 3 of the Charter, the United Nations (i.e., countries belonging to the United Nations - UN) have to: lead to international cooperation in solving issues of an economic, social, cultural or humanitarian nature, as well as to encourage and encourage respect for human rights and fundamental freedoms for all, regardless of race, sex, language or religion (Charter, 1945).

The UN created in 1945, as part of its activities, based on the UN Charter, implements humanitarian activities through structural agendas, according to their areas of competence. The agendas are (Grzebyk \& Mikos-Skuza, 2016)

- The UN Office for the Coordination of Humanitarian Affairs (OCHA) - its purpose is to coordinate humanitarian aid provided by various humanitarian actors;

- The Office of the UN High Commissioner for Refugees (United Nations High Commissioner for Refugees - UNHCR);

- World Food Program (WFP);

- United Nations Children's Fund (UNICEF);

- United Nations Development Program (UNDP);

- The United Nations Food and Agriculture Organization of the United Nations (FAO);

- World Health Organization (WHO);

- International Organization for Migration (IOM).

Peace operations (missions) have become one of the main tools of the UN's activities in the field of international security. Among the United Nations' peace support operations, humanitarian aid 
operations are coordinated by the United Nations Office for the Coordination of Humanitarian Affairs $(\mathrm{OCHA})$. This assistance is provided in the case of natural disasters or armed conflicts when national authorities are unable to act effectively and help their citizens. The United Nations provides emergency relief as well as complex humanitarian actions (Long-term Action). The UN also supports actions carried out by governments of countries affected by fate and organizations specialized in aiding (EUCOUNCIL, 2008).

The International Movement of the Red Cross and Red Crescent Movement (IMRC and RCM) is a humane organization with representatives in most countries of the world, founded for victims of military activities and gradually expanding its activities to all those in need, the sick and the suffering (Britannica - Polish edition, 2002).

The purpose of the IMRC and RCM's activity is "to prevent and mitigate human suffering and to protect human dignity, without any discrimination", ensuring protection and humanitarian treatment of victims of wars and armed violence. The Committee has a permanent international mandate to intervene on prisoners and prisoners of war, wounded and sick, including civilians affected by conflict. It also aids victims of natural disasters, accidents and epidemics in the period of peace, deals with the dissemination of health education and the organization of blood donation.

The peaceful activity of the organization includes first aid, accident prevention, safety on waters, nursing and obstetric training, maintenance of mother and child care centers, medical clinics, blood banks and provision of related services. During the wars, the committee acts as a mediator between the feuding parties and national organizations. It has the right to visit POW camps, provide medical assistance, mail and information about people in the camps. The League of Red Cross and Crescent Societies with the secretariat in Geneva provides assistance to victims of natural disasters and supports the development of national organizations Compare: (Britannica..., pp. $245-246)$.

The North Atlantic Treaty Organization (NATO) conducts numerous crisis response operations. NATO operations are different from operations carried out by the UN in structure, character, scope of activities and preparation of forces intended to conduct operations in the event of a crisis.

The Peace Support Operation (PSO) is a multifunctional operation carried out with respect for the principles of impartiality under the auspices and from the UN mandate, and sometimes under the Organization for Security and Cooperation in Europe (OSCE) with the involvement of armed forces, diplomatic and humanitarian agencies, to achieve long-term political agreement or other objectives defined by the mandate. PSOs include activities such as (Bąk, 2012):

- Peacekeeping - PK;

- Peace enforcement - PE;

- Conflict prevention - CP;

- Peace-making - PM;

- Peace building-PB;

- Humanitarian operations - HO.

The NATO humanitarian operations are conducted to aid the civilian population. These operations are conducted by military contingents (independently) and in cooperation with specialized civilian organizations (e.g. Red Cross and Red Crescent). The purpose of these operations is to help in cases of human rights violations, natural disasters, and epidemics. According to the new NATO Reaction Strategy, humanitarian operations are divided into humanitarian assistance and disaster relief. Humanitarian aid does not have to be carried out as a typical humanitarian operation, but it can also be carried out as part of any peace support operation (2014).

Humanitarian aid is also provided by the European Union (EU), based on a system of institutions, the foundations of which the base are the EU Council (the main decision-making body of the European Communities), the European Parliament (a unicameral parliament representing the EU's citizens), the European Commission (type of the EU government), the Economic and Social Committee (EU advisory body), the Committee of the Regions (advisory and consultative body), the Court of Justice (one of the main bodies of the European Communities, acting as an international, constitutional and administrative court). Union actions in the field of humanitarian aid shall be carried out in accordance with the principles and objectives of the Union's external actions. These activities are intended to provide 
emergency assistance and care to people in third countries who have been victims of natural disasters or man-made disasters and to protect them in order to meet the humanitarian needs arising from such different situations. The actions of the Union and the Member States are mutually reinforcing and complement each other (Article 214.1 of the Treaty on the Functioning of the EU) (EC, 2000)

The basic objective of the EU's humanitarian policy is to provide emergency assistance to victims of natural disasters and man-made disasters. The EU Treaty defines the notion of humanitarian aid provided by the Union and the Member States. Union policy in the field of humanitarian aid is governed by a Council Regulation which defines, inter alia, the main objectives of humanitarian aid to third countries. It lists the following (EC, 2000):

- saving and protecting life during critical situations and directly in their sequence and during natural disasters;

- providing necessary assistance and support to people exposed to long-lasting crises resulting from outbreaks of fighting or wars, when their own governments are not able to provide assistance or assistance cannot be granted due to the lack of appropriate authorities:

- assistance in financing the transport of humanitarian aid through all available logistical means and protection of goods and personnel serving humanitarian purposes;

- carrying out short-term works related to the reconstruction of damaged infrastructure;

- overcoming difficulties related to the consequences of migration of the population (refugees, displaced persons and repatriates) caused by natural disasters or catastrophes caused by human activities, and carrying out aid programs dealing with repatriation to the country of origin and resettlement in it, if the conditions laid down in the applicable international agreements are fulfilled,

- preparing the population for the risk of a natural disaster or comparable exceptional circumstances and using a sufficiently rapid early warning and intervention system;

- supporting activities to protect victims of fighting or comparable critical situations, in accordance with applicable international agreements.

Apart from humanitarian aid directed to third countries, the EU also has instruments for civil protection in the European territory. In addition to humanitarian aid directed to third countries, the EU has instruments for civil protection in the European territory. The Civil Protection Mechanism (CPM) created in 2001 (Zbroina, 2011) a key instrument of European civil protection. The mechanism was established by the decision of the EU Council of 23 October 2001 establishing a Community mechanism to facilitate reinforced cooperation in interventions supporting the protection of populations. The main goal of creating the Mechanism was the need to strengthen cooperation between the Community and the Member States during the relief operation, being a reaction to the occurrence of natural, technological, radiological or ecological disasters. The mechanism is a tool to increase security, as well as an effective means of ensuring the integration of emergency services of European countries. After fulfilling certain conditions, it is also possible to use it in crisis management operations as a tool for facilitating and supporting the operation. It can be used on EU territory or outside its borders. Assistance may be in the form of material help, sending equipment and teams or experts involved in the assessment of the consequences of the disaster. The type of assistance depends on the resources possessed by the sending State (Zbroina, 2011). The operational heart of CPM is the Monitoring and Information Center (MIC) operating in the European Commission, operating 24 hours a day, if necessary. MIC, collects and confirms information on the threat and distributes it to the contact points of countries - participants of the Mechanism, and facilitates the mobilization of rescue groups and experts, the so-called civil protection modules. The Polish point of contact is the National Center for Coordination of Rescue and Civil Protection of the State Fire Service. The population protection module is based on the strengths and resources of the Member States concerned, adapted to perform pre-defined tasks and meeting specific needs, or a mobile operational response team of the Member States, which includes both human and material resources (Zbroina, 2011). 
EU humanitarian aid is carried out as part of general international activities that unite the UN, the International Red Cross and Red Crescent Movement ( $\mathrm{RC}$ and $\mathrm{RCM}$ ), non-governmental humanitarian organizations and other entities, and their aim is only to support local actions taken in response to humanitarian crises, because the main responsibility for civil protection in the face of a disaster is borne by the national authorities of states in a crisis. The Humanitarian Aid Directorate (ECHO) Compare: (Kienzler, 2003, p. 45 ) is the organization for providing humanitarian aid at EU level.

Poland has a significant contribution to the implementation of humanitarian aid under CPM. The State Fire Service has rescue modules registered in the CECIS system (The Common Emergency Communications and Information System). This system was created to ensure communication between the Member States of the Civil Protection Mechanism and between the Member States and the MIC in Brussels. CECIS is one of the essential elements of the Mechanism since it should guarantee the authenticity, integrity, and confidentiality of information exchanged between participating countries in the Mechanism under routine conditions, as well as in all kinds of critical situations.

The non-governmental sector, which includes international, regional and local entities that implement specific rescue support activities, works in close cooperation with governmental organizations and UN agencies, including Doctors without Borders, Peace Corps, Polish Humanitarian Organization, Polish International Aid Center. Summing up, it should be noted that multilateral cooperation and humanitarian aid is part of the following international organizations: UN, EU, NATO, OECD, the Council of Baltic Sea States, Visegrad Group, Central European Initiative.

The leading and well-known Polish humanitarian organizations that provide humanitarian assistance both at home and abroad are the Polish Humanitarian Organization, Caritas Poland and the Great Orchestra of Christmas Charity. In addition, various types of smaller and larger foundations operate in the area of humanitarian aid, specializing in helping certain social groups or supporting specialist treatment (e.g. TVN Foundation, Anna Dymna Foundation, and others).

\section{CONCLUSIONS}

Humanitarian aid is extremely desirable and expected especially in events that threaten a large human population. Developed countries understand the necessity of providing help and sharing their acquis with the needy. Hence, international, intergovernmental and nongovernmental organizations have been established which professionally deal with the provision of humanitarian aid. This assistance in the form of material help, sending equipment and teams or experts, takes place according to the rules and principles adopted by the signatories of individual humanitarian organizations.

In today's world, where the development of events threatening the life and health of people is unpredictable, humanitarian aid may be necessary not only in weak, developing countries but also in countries that today seem to be selfsufficient.

\section{WORKS CITED}

Bak, T. (2012). Misje stabilizacyjne i operacje pokojowe metoda rozwiazywania konfliktow militarnych. Zeszyty Naukowe WSOWL, 1 (163), 201.

Britannica - Polish edition. (2002). Poznan: Wyd. Kurpisz.

Charter, U. N. (1945, June 26). Charter of the United Nations. Retrieved from United Nations: http://www.un.org/en/charter-united-nations/

EC. (2000). ABC Unii Europejskiej. European Commission. Nice: European Commission. Retrieved from http://www.uw.olsztyn.pl/inte/05A.htm

EUCOUNCIL. (2008, 0130$)$. THE EUROPEAN CONSENSUS ON HUMANITARIAN. Official Journal of the European Union, 1.

Grzebyk, P., \& Mikos-Skuza, E. (2016). Pomoc humanitarna w swietle prawa i praktyki. Warszawa: Scholar. 
Kienzler, I. (2003). Leksykon UE. Warszawa: Swiat Ksiazki.

Kuzniak, B., \& Marcinko, M. (2013). Organizacje miedzynarodowe. Warszawa: C. H. Beck.

Latoszek, E., \& Proczek, M. (2001). Organizacje miedzynarodowe. Zalozenia, cele, dzialalnosc. Warszawa: Dom Wydawniczy Elipsa.

Leksykon PWN. (1999). Warszawa.

Operacje reagowania kryzysowego $w$ ramach NATO. (2014, Dec 19). Retrieved from NOWA strategia.org.pl: www.nowastrategia.org.pl/operacje-reagowania-kryzysowego-w-ramach-nato

Simak, L. (2004). Krizovy manazment voverejnej sprave, FSI ZU (tretiedoplnenevydanie ed.). Zilina: FSI ZU Detasovane pracovisko Kosice.

Simak, L., \& Ristvej, J. (2009, Apr 7). The Present Status of Creating the Security System of the Slovak Republic after Entering the European Union. Simak, L. \& Ristvej, J. (2009). The Present Status of Creating the Security System of the Slovak Republic after Entering the European Union. Journal of Homeland Security and Emergency Management, 6(Article 20). doi:10.2202/15477355.1443

Simak, L., Seidl, M., \& Zamiar, Z. (2009). Aktualne problemy zarzadzania kryzysowego. Wrocław: CL Consulting i Logistyka.

Zagorecki, A., Ristvej, J., Comfort, L., \& Lovecek, T. (2012). Executive Dashboard Systems for Emergency Management, Communications. Scientific Letters of the University of Zilina, Vol. 14, p. $82-89$.

Zbroina, J. P. (2011). Znaczenie oceny zgodnosci dla ochrony przeciwpozarowej i ochrony ludnosci. Centrum Naukowo-Badawcze Ochrony Przeciwpozarowej im. Jozefa Tuliszkowskiego Państwowy Instytut Badawczy.

Zygierewicz, A. (2011, 02 02). Pomoc humanitarna Unii Europejskiej. Retrieved from DOCPLAYER: http://docplayer.pl/40589-Pomoc-humanitarna-unii-europejskiej.html

Received for publication: $\quad$ 07.02.2018

Revision received: $\quad 12.06 .2018$

Accepted for publication: $\quad 22.06 .2018$

\section{How to cite this article?}

Style - APA Sixth Edition:

Paweska, M. (2018, July 15). Logistics for Humanitarian Aid. (Z. Cekerevac, Ed.) MEST Journal, 6(2), 89-96. doi:10.12709/mest.06.06.02.11

Style - Chicago Sixteenth Edition:

Paweska, Marcin. 2018. "Logistics for Humanitarian Aid." Edited by Zoran Cekerevac. MEST Journal (MESTE) 6 (2): 89-96. doi:10.12709/mest.06.06.02.11.

Style - GOST Name Sort:

Paweska Marcin Logistics for Humanitarian Aid [Journal] // MEST Journal / ed. Cekerevac Zoran. Toronto : MESTE, July 15, 2018. - 2 : Vol. 6. - pp. 89-96.

Style - Harvard Anglia:

Paweska, M., 2018. Logistics for Humanitarian Aid. MEST Journal, 15 July, 6(2), pp. 89-96.

Style - ISO 690 Numerical Reference:

Logistics for Humanitarian Aid. Paweska, Marcin. [ed.] Zoran Cekerevac. 2, Toronto : MESTE, July 15, 2018, MEST Journal, Vol. 6, pp. 89-96. 